\begin{tabular}{llllllll} 
O P E R A T I O N S R E S E A R C H A N D D E C I S I O N S \\
\hline No. 3
\end{tabular}

DOI: $10.37190 /$ ord200304

\title{
ASSESSMENT OF STRATEGIC DECISIONS OF ENTERPRISES OPERATING IN INTERNATIONAL MARKETING IN THE ERA OF MODERN TECHNOLOGIES
}

\author{
MAŁGORZATA ŁĘGOWIK-MAŁOLEPSZA* \\ Częstochowa University of Technology, ul. Dąbrowskiego 69, 42-201 Częstochowa, Poland
}

\begin{abstract}
The issue of assessment of strategic decisions in the company has been approached while indicating their impact on the implementation of modern technological solutions and the methods for their financing. The essence of the strategy of the company has been presented, taking into account the impact of strategic decisions on the changes in the adopted strategy of the enterprise based on the literature studies. The considerations presented in the empirical part include the results of the research conducted in the multinational chemical company. The objective of the study was to learn and assess the relationships between the implementation of modern technological solutions and the effectiveness of strategic decisions on the methods for their financing. The research methods applied to accomplish the objective are literature studies, a case study and the following techniques related to analysis are used: the analysis of return on investment, and the analysis of financial leverage effect. The issue of assessment of strategic decisions is important and up-to-date due to its impact on the continuity of business operations and maintaining a competitive advantage on the market. This study is an attempt to fill the observed research gap regarding the relationships between the implementation of modern technological solutions and the effectiveness of strategic decisions on the methods for their financing.
\end{abstract}

Keywords: strategic decisions, multinational companies

\section{Introduction}

The development of the conceptual basis for building a competitive advantage in the contemporary enterprise requires not only the integration of the strategy with the area of corporate finance, but also taking into account new technologies which are defined as technologies "in the form of industrial property rights or results of development works, or results of application research, or non-patented technical knowledge that allows the production of new or significantly improved products, processes or services" [24].

*Email address: m.legowik-malolepsza@pcz.pl

Received 5 February 2020, accepted 16 October 2020 
Managers are willing to reach for such modern technologies that enable the identification and use of the company's potential to meet the expectations of both shareholders and other stakeholders in the business environment [20]. Technological progress provides modern tools that enable current changes or correction of the adopted strategy by providing additional information about operating conditions in the turbulent environment. The implementation of modern technological solutions is particularly important for enterprises operating internationally. Searching for, testing, and introducing modern technologies require large financial outlays. Therefore, enterprises operating in international markets, wishing to maintain their market position [8], should take into account the technological development in the company's strategy.

Therefore, in this study, the following research question was formulated: do enterprises operating in international markets which implement modern technological solutions assess the effectiveness of strategic decisions on the methods of financing to maintain their position in the competitive market? As a result of the question, the objective of the study is to learn and assess the relationships between the implementation of modern technological solutions and the effectiveness of strategic decisions on the methods for financing these solutions. The research methods applied to accomplish the objective include literature studies, a case study, the analysis of return on capital employed, as well as the analysis of financial leverage effect. The empirical research is conducted based on the data from the financial statements of the three subsidiaries of the selected chemical industry company conducting their business activities in Poland, Austria, and Hungary. The research period is the years 2010-2018.

\section{Strategies of enterprises. Theoretical approaches}

The strategy defines and formalises how the objectives of the enterprise will be accomplished [7]. At the same time, the strategy is both the idea and the set of policies and procedures which operationalise this idea [18]. This means that the strategy plays the role of the model of operation of the enterprise [22]. As pinpointed by Moszkowicz [14], the strategy is the way of conduct which allows the company to maintain beneficial, with the given criteria, stability concerning the environment. In turn, Romanowska [19] emphasises that the strategy is a dynamic process of overcoming difficulties which enterprises face on the way of their development.

A properly formulated strategy should enable building the competitive advantage of the company, considering all areas of its operation as well as actions taken to accomplish the assumed objectives [17]. According to Hazen and Byrd, competitive advantage shows a firm's capability to create a secured position over its competitors because of a critical business decision [14]. A source of the competitive advantage of the company can be creating a strategy based on the potential of modern technological solutions if it 
includes the use of resources and skills [12]. The competitive advantage, from the perspective of modern technologies, should distinguish the company from its competitors so that it will generate greater benefits than its competitors. In terms of this approach, the strategy based on the implementation of modern technologies should lead to higher sales, lower costs, and higher quality of products offered [10].

The assessment of the implemented strategy requires the choice of selected measures which must be individually adjusted to the enterprise, considering the principle of the right order of strategic components [15]. The measures used to assess the strategy should focus on the main objective and the sub-objectives accepted for the implementation. Therefore, the applied measures should reflect the economic content of the activity conducted by the company as well as provide management information [21] necessary to make the right decisions. At the same time, the measures used to assess the implementation of the strategy should facilitate communication within the company for better adjustment to changes in its environment. This means that strategic measures ought to be individually tailored to the specific type of business activity and, at the same time, provide information which reflects all aspects of the conducted activity.

Summing up the review of the presented definitions, it should be stated that the strategy should allow the enterprise to achieve and maintain the advantage in the competitive market. Moreover, the implementation of the adopted strategy ought to undergo periodic evaluation. If the assumed strategy does not bring the intended effects, it should be changed for improvement in the operation of the company within the framework of the available resources, considering external and internal conditions.

\section{Strategic decisions and the change in the company's strategy}

The decision-making process in the company is streamlined using the concept of decision-making models which allow for a rapid change in the company's strategy [5]. Following the dynamic approach in the theory of management, decision-making models are a static representation of the adopted strategy [16]. Moreover, they constitute a tool presenting the logic of operation of enterprises in the specific field, including a set of components and relationships between these components [19].

Strategic decisions relate to the accomplishment of long-term objectives. The scope of the problem being solved and the involvement of resources in the case of strategic decisions is visible in the long-term perspective [3]. Therefore, the decision-maker, in the case of strategic decisions, should look for an optimum solution to the specific problem [25]. Making changes in the business strategy requires not only the good knowledge of the company [11] but also recognition of environmental factors and identification of risk factors in the area of the implemented strategy [23]. This means that the decisionmaker should have an impact on the decision-making process, which is subjected to 
confrontation in the existing structures of the company. The occurrence of changes in the micro and macro environment determines the structure of games and the direction of the adopted strategy [2].

The effectiveness of strategic decision-making is determined by the ability to identify and analyse risk factors. Therefore, risk management in terms of strategic decision-making is associated with the level of risk as well as taking actions to counteract the negative effects of risk, relating to the enterprise. Risk management ought to consider the analysis of the vulnerability of the company to the identified risk factors. The identification of factors generating risk consists of specifying the greatest threats and places where they may occur. Based on the identified risk factors, the company develops the risk management strategy and defines mechanisms and operations which are essential for the implementation of the assumptions of the adopted strategy [1].

The correct assessment of the effectiveness of risk management is the basis for strategic decisions. The basic components of the risk management process presented in the subject literature are: defining the objectives and tasks of risk management, specifying the factors generating risk, developing the risk management strategy, designing and introducing mechanisms for monitoring the risk using selected measures, verifying the effectiveness of risk monitoring procedures and facilitating risk management mechanisms [9].

It should be concluded that strategic decision-making processes should consider the identification and analysis of risk factors. Not all risk factors can be eliminated. However, aiming at the minimisation of the identified risk brings effects in the form of the accomplishment of the assumed strategic objectives. Moreover, early identification and analysis of risk factors allow for the change in the company's strategy and flexible adaptation to changes in the environment.

\section{Methodology of the empirical research}

The cognition and assessment of the relationships between the implementation of modern technological solutions and the effectiveness of strategic decision-making in terms of the methods for financing these solutions was carried out based on the empirical research conducted in the multinational chemical company, using purposive sampling (the availability of empirical data). The surveyed entity has the subsidiaries in Austria, Poland, and Hungary, which are conventionally labelled as companies A, B, and C, respectively. The research period was the years 2010-2018. The surveyed enterprises use international marketing which is defined as "the performance of business activities that direct the flow of a company's goods and services to consumers or users in more than one nation for a profit" [6]. 
In the analysed chemical industry company, the technology of augmented reality (AR) around warehousing and transport was implemented. The objective of the introduction of AR was to reduce the costs of the conducted activity, improve the quality of the provided products. and increase sales. The implementation of AR solutions requires capital expenditures incurred by the surveyed company. Therefore, the basis for learning and assessing the effectiveness of strategic decision-making in terms of the methods for financing modern technological solutions in the analysed entity is to possess necessary information about the course of economic processes [4].

An important source of information is relative numbers, expressed through indicators, which enable the interpretation of certain economic values at various levels of the company's operation. The empirical research was conducted based on the analysis of financial statements using selected financial indicators.

The research process took place in two stages. In the first stage, the research tool enabling learning and assessing the effectiveness of strategic decisions in terms of the methods for financing modern technological solutions was the rate of return on investment (employed capital), to provide information about the development potential and strategic decisions concerning investments in new technologies of the surveyed companies. In the second stage of the empirical work, the analysis of the financial leverage ratio was carried out, delivering information about the impact of foreign capital on the level of return on capital employed, which allows the assessment of strategic decisions, concerning the effectiveness of using foreign capital to finance investments in modern technological solutions.

\section{Assessment of strategic decisions on the methods for financing modern technological solutions. A case study}

The selection of the rate of return on investment to learn and assess the relationships between the implementation of modern technological solutions and the effectiveness of strategic decision-making in terms of the methods for financing these solutions, in the first stage, was determined by the assumed methodological objectives following which the system of indicators allows obtaining the information on the implementation of strategic decisions in terms of the methods of financing and enables the comparability of results in the surveyed companies over the time. The analysis of return on investment allows the assessment of financial and organisational factors affecting the effectiveness of investment activities of the analysed company, taking into account the expenditures incurred on the implementation of the AR technology in the area of warehousing and transport. Moreover, the rate of return on investment allows obtaining a wide range of information for the analysis of decision-making processes in the area of the rate of return and directions of capital investment. 
For the assessment of development opportunities in the surveyed company, the rate of return on investment (also known as the rate of return on capital employed) was analysed. In 2010, in the company, AR solutions were implemented in the devices supporting operations associated with warehouse management, through which the performance of workhouse operations was increased. By introducing the AR navigation indoors, the faster and more efficient picking of products for shipping was achieved, while directing the warehouse worker to fetch subsequent products needed to be packed using the shortest way. When analysing the rate of return on investment in the years 2010-2013, an upward trend can be observed in company A. In the years 2014-2015, there was a slight decrease in the value of the indicator. However, since 2016 the level of return on investment in the company has been the evidence of maintaining financial balance and great development opportunities, even in the case of the economic downturn in the market of chemical products (Fig. 1).

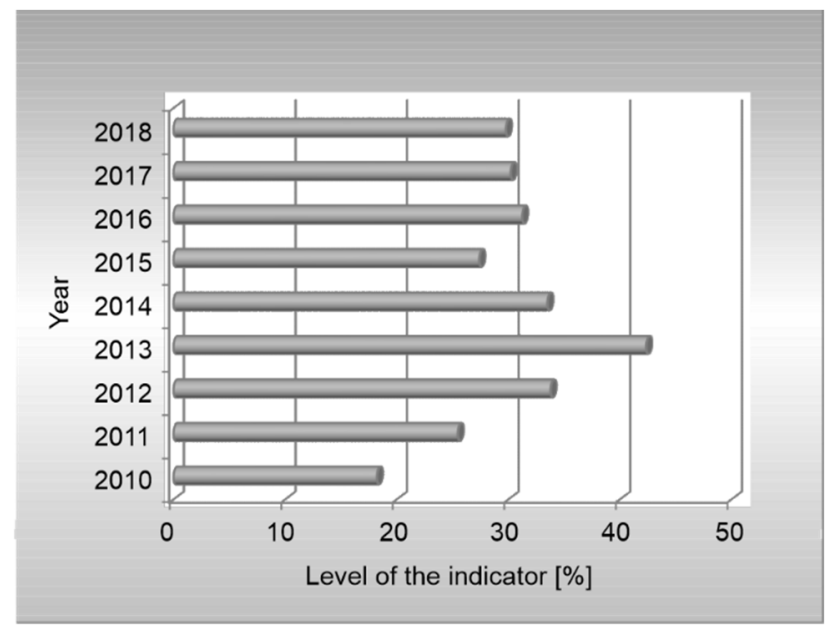

Fig. 1. The level of return on investment in company A in the years 2010-2018

Company B, also in 2010, introduced the devices equipped with the AR software for order picking, analysing the scope of the order fulfilled. When analysing the level of the rate of return on investment in company B, the dynamic growth in the value of the indicator can be observed from the level of $20 \%$ in 2010 to $60 \%$ in 2013. A decrease in the level of the analysed indicator in the years 2014-2015 was the result of the downturn in the market of chemical products in that period (Fig. 2).

Since 2016, the level of the rate of return of investment in company B has shown an upward trend. The surveyed company has large development potential and strategic decisions taken in the field of investment, capital structure, and the share of long-term liabilities contribute to the maintenance of financial balance. 


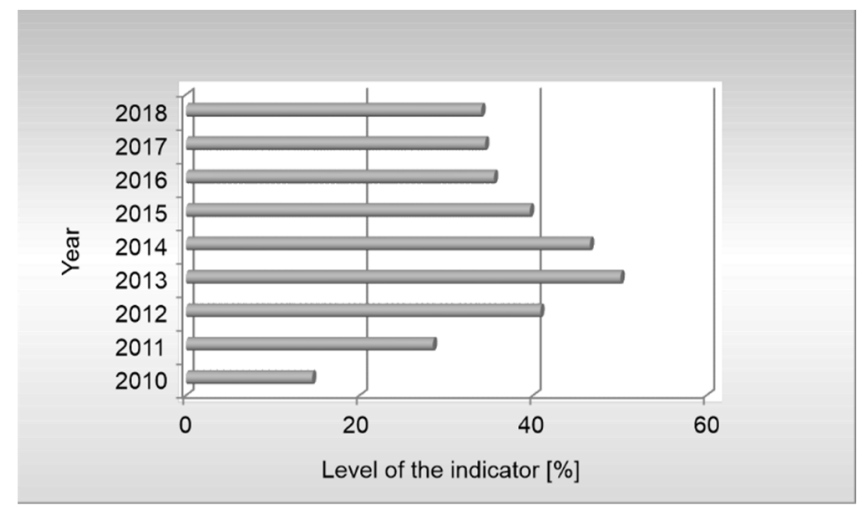

Fig. 2. The level of return on investment in company B in the years 2010-2018

In company $\mathrm{C}$, the devices equipped with the AR software were also implemented. The realised investments allowed for reducing the number of errors in warehousing processes by accelerating the work of employees, which positively influenced an increase in the productivity and effectiveness of the warehouse in the years 2010-2012 (Fig. 3).

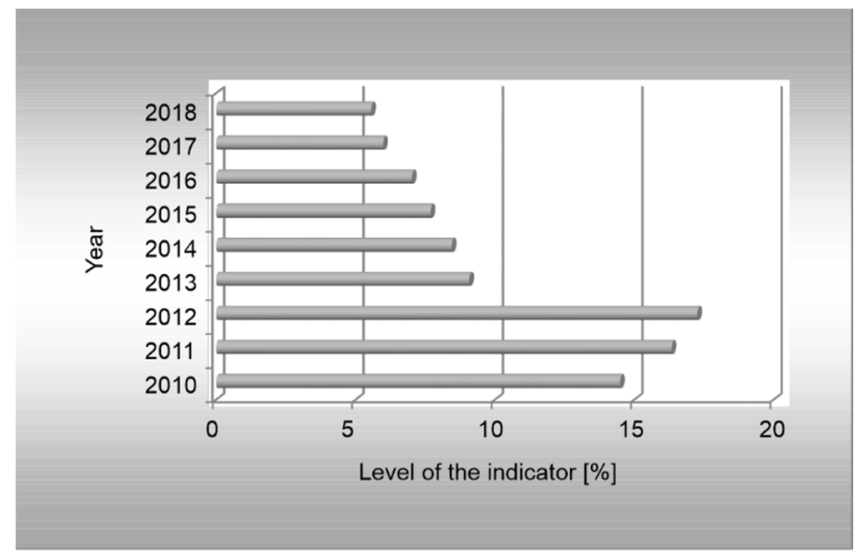

Fig. 3. The level of return on investment in company C in the years 2010-2018

The analysis of the rate of return on investment of company $\mathrm{C}$ indicates that the subsequent investments in the modernisation of the assembly line realised in 2012, simultaneously accompanied by a decrease in the demand for the manufactured products, were the immediate cause of the deterioration of the financial condition of company $\mathrm{C}$. In the years 2013-2018, there was a decrease in the level of the rate of return on investment in company $\mathrm{C}$, which resulted in the financial imbalance of the analysed company.

In the second stage of the implementation of empirical research, the leverage ratio was analysed, which provides information on the involvement of foreign capital in investment and financial processes. The upward trend of the leverage ratio informs that, 
in company A, the proper investment policy in the area of capital structure was conducted, which had an impact on good economic results of the analysed company throughout the research period (Fig. 4).

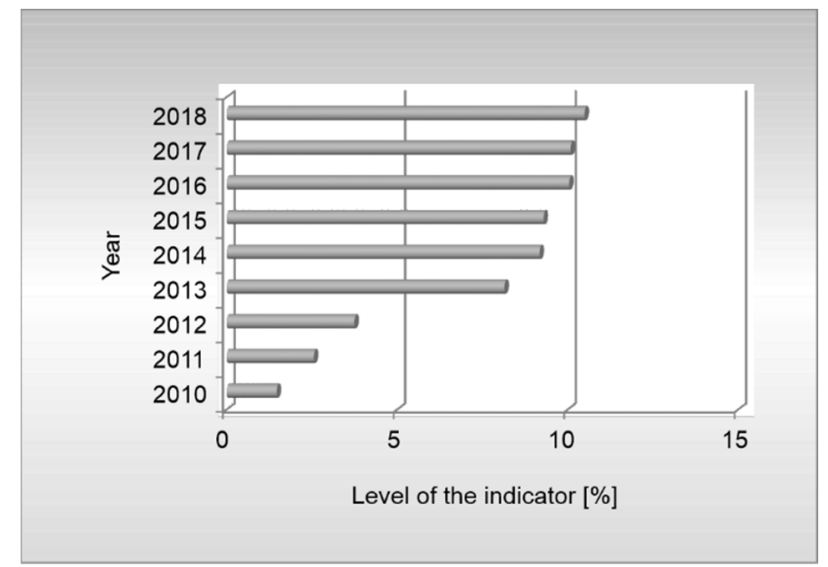

Fig. 4. The level of financial leverage in company A

Company B indicates a positive financial leverage effect throughout the research period. In 2015, there was a decrease in the leverage ratio but the relationship between capital structure and return on equity ratio remained at a stable level. Therefore, a positive financial leverage effect in that period did not interfere with the profitability of company B (Fig. 5).

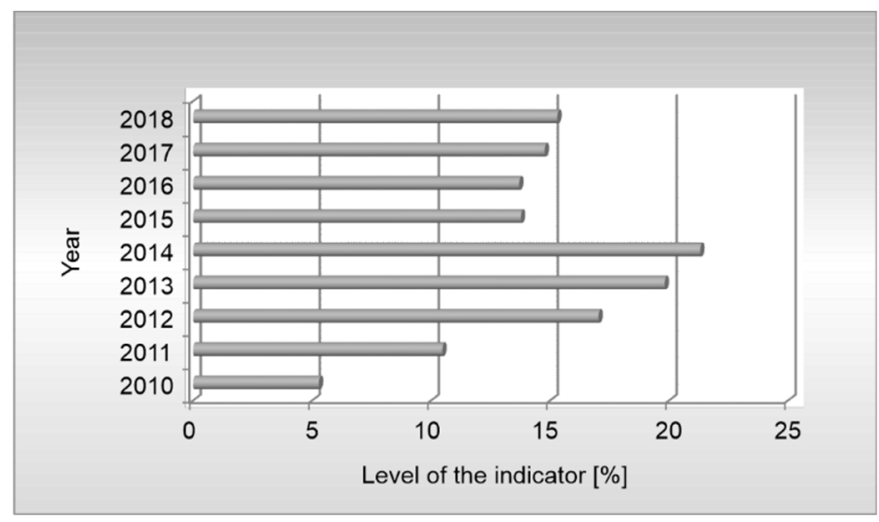

Fig. 5. The level of financial leverage in company B

The financial leverage effect in company $\mathrm{C}$ in 2010 had a positive value. In 2012, there was an increase in the ratio. A decrease in the value of the indicator in 2013 was the evidence of a high share of debt in the capital of company C (Fig. 6). 
In 2014, the capital structure was corrected. The subsequent years brought a positive return on equity ratio, informing that the interest rate on debt did not exceed the profitability of the entire capital of the surveyed company (Fig. 6), and the relationship between capital structure and return on equity ratio in company $\mathrm{C}$ began to stabilise.

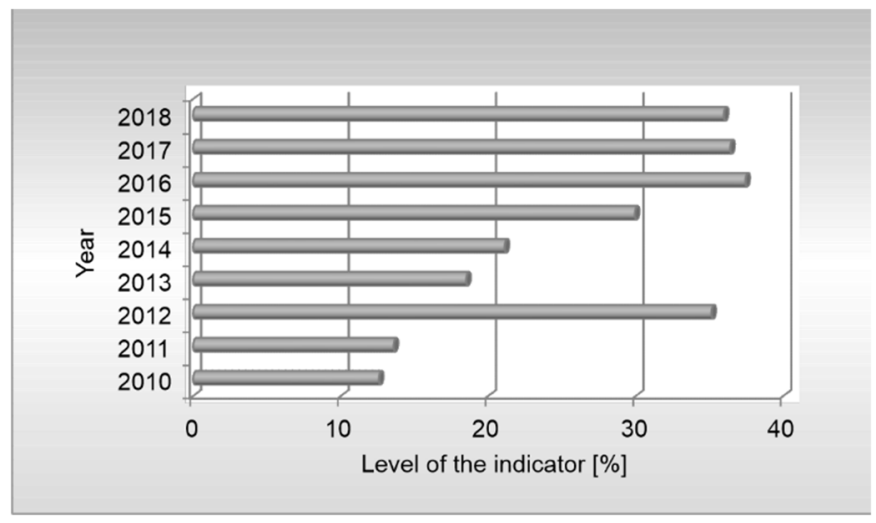

Fig. 6. The level of financial leverage in company $\mathrm{C}$

Summing up the results of the empirical research in the field of the analysis of return on investment, it should be concluded that, in companies A and B, similar strategic decisions are taken in terms of investment and financial policies. Company $\mathrm{C}$ uses a different model of strategic decision-making (a high share of foreign capital in the capital structure), which caused that the beginning of costly investments and the downturn in the market of the products offered led to a significant deterioration in the financial condition of the company.

When analysing the financial leverage effect, a strong relationship between capital structure and return on equity can be observed in the three entities of the analysed chemical company, which reflects strategic decisions taken in the area of co-financing the conducted activity with foreign capital. The use of the financial leverage effect requires taking into account both the current situation of the analysed enterprises in the decisionmaking process and forecasts for the future, in particular when decisions are to relate to the implementation of future investment projects.

\section{Conclusions and discussion}

When answering the question if enterprises operating in international markets which implement modern technological solutions assess the effectiveness of strategic decisions on the methods for financing to maintain their position in the competitive market, it should be concluded that enterprises operating in international markets ought to take 
into consideration specific conditions for conducting activities in various markets. The objective of the study is to learn and assess the relationships between the implementation of modern technological solutions and the effectiveness of strategic decision-making in terms of the methods for financing these solutions. The main contribution of the article is a better understanding of the process of strategic decision-making of enterprises operating in international markets, which should be characterised by the ability to adapt to changes. It should be added that the implementation of technological advancements contributes to the increase in the competitiveness of enterprises by meeting the current expectations and the needs of customers.

The conducted empirical research in the field of return on investment and financial leverage effect in the three entities of the analysed chemical company provides the information on the effectiveness of strategic decisions taken in the area of investments in modern technologies and the methods for their financing, at the same time being the basis for forecasting future directions of enterprise development. Strategic decisions concerning the structure of equity and the level of involvement of foreign capital in financing investments in new technologies affect the level of the financial result of the analysed entities, therefore their efficiency has an impact on the ability to continue operations. This means that strategic decisions are becoming an important parameter affecting the level of profitability in the surveyed chemical company, since they may contribute to the growth in the development potential or significantly weaken the financial condition of the unit in the case of failed investments. However, it should be pinpointed that the presented indicators have a limited field of reception, therefore it becomes purposeful to obtain a complete assessment in dynamic terms by conducting detailed analysis in the entities.

The recommendation for the surveyed company is to search for new methods for financing modern technological solutions which must consider the strategic decisionmaking process to achieve higher efficiency of operations. The multidimensionality of the issue of management of the company operating in international markets has caused that, in the study, some of the considerations are presented in general terms, which, on the one hand, allows for highlighting the complexity of the discussed subject matter and, on the other hand, inspires for further research and exploration.

\section{References}

[1] Alexander D., Britton A., Financial Reporting, Thomson, 2001, 75.

[2] BojAR E., FreITAG-MikA E., Objectives of competitive strategy of the transnational corporation in conditions of globalization, [In:] J. Seppand, D. Frear (Eds.), Globalization and Institutional Development, Congress of Political Economists International, USA, Wilkes-Barre 2008, 139-157.

[3] Bolesta-KukuŁKa K., Managerial Decisions, PWE, Warsaw 2007, 51 (in Polish).

[4] Strategic Information System. Economic Intelligence and Business Competitiveness, R. Borowiecki, M. Romanowska (Eds.), Difin, Warsaw 2001, 28 (in Polish). 
[5] Bratnicka K., Dyduch W., Strategic entrepreneurship. Concept and measurement, [In:] R. Krupski (Ed.), Strategic Management. Development of Concepts and Methods, Prace Naukowe WWSZIP, 2014, 27 (2), 167 (in Polish).

[6] CATEORa P.R., GhauRi P.N., International Marketing, McGraw-Hill Publishing Company, European Edition, 1999.

[7] Chan Kim W., Mauborgne R., Blue Ocean Strategy, MT Biznes, Warsaw 2007, 42-43 (in Polish).

[8] DE Wit B., Meyer R., A Synthesis of the Strategy. Creating a Competitive Advantage by Analysing Paradoxes, PWE, Warsaw 2007, 147 (in Polish).

[9] Deloach J., Temple N., Enterprise-Wide Risk Management. Strategies for Linking Risk and Opportunity, Financial Times, Management Briefings, 2000, 26-28.

[10] Dudycz T., Managing Company Value, PWE, Warsaw 2005, 31 (in Polish).

[11] HAMEL G., Competition for Competence and Interpartner Learning within International Strategic Alliances, Strat. Manage. J., 1991, 12 (51), 83-103.

[12] Hamel G., Leading the Revolution, Harvard Business School Press, Boston 2002, 59-68.

[13] Hazen B.T., Byrd T.A., Toward Creating Competitive Advantage with Logistics Information Technology, Int. J. Phys. Distr. Log. Manage., 2012, 42 (1), 8-35.

[14] Strategic Management. Systemic Business Concept, M. Moszkowicz (Ed.), PWE, Warsaw 2005, 47-48 (in Polish).

[15] NIEMCZYK J., Strategy. From Plan to Network, Wydawnictwo Uniwersytetu Ekonomicznego we Wrocławiu, Wrocław 2013, 35 (in Polish).

[16] Nogalski B., Model and business strategy, [In:] M. Nowicka-Skowron (Ed.), Managing Networks of Cooperation in the Process of Building an Innovative Organisation and Region, Sekcja Wydawnictw Wydziału Zarządzania Politechniki Częstochowskiej, Częstochowa 2009, 28 (in Polish).

[17] Porter M., Competitive Advantage. Achieving and Maintaining Better Results, Helion, Gliwice 2006, 35 (in Polish).

[18] Rokita J., Strategic Management. Creating and Maintaining a Competitive Advantage, PWE, Warsaw 2005, 24 (in Polish).

[19] Romanowska M., Strategic Planning in the Company, PWE, Warsaw 2005, 19 (in Polish).

[20] Romanowska M., Strategic Breakthroughs in the Company, Studia i Prace Kolegium Zarządzania i Finansów SGH, No. 98, Oficyna Wydawnicza SGH, Warsaw 2010, 8 (in Polish).

[21] StabryŁa A., Research Directions for the development of managerial information systems, [In:] R. Borowiecki, J. Czekaj (Eds.), Managing Information Resources in the New Economy, Difin, Wrocław 2010, 22 (in Polish).

[22] StabryŁa A., Strategic Management in Company's Theory and Practice, Wydawnictwo Naukowe PWN, Warsaw 2002, 39-40 (in Polish).

[23] STRUŻYCKi M., Introduction, [In:] M. Strużycki (Ed.), Basics of Management, Oficyna Wydawnicza Szkoły Głównej Handlowej w Warszawie, Warsaw 2014, 11 (in Polish).

[24] Act of 30 May 2008 on certain forms of support for innovative activity, Dz.U. 2008, Nr 116, poz. 730, (Dz.U. 2019, poz. 1402, 2020, poz. 568) (in Polish).

[25] ŻUBER R., Managing Company Development. Theory and Practice, Difin, Warsaw 2008, 16 (in Polish). 